\title{
Sediment filtration in a montane riparian zone under simulated rainfall
}

\author{
ROBERT A. PEARCE, GARY W. FRASIER, M. J. TRLICA, WAYNE C. LEININGER, JOHN D. STEDNICK, AND \\ JAMES L. SMITH
}

Authors are with EnviroCounsel Consulting, P.O. Box 54, Big Pine, California, 93513; research hydraulic engineer, USDA Agricultural Research ServiceRangeland Resources Research Unit, 1701 Center, Fort Collins, Colo, 80526; professor and associate professor Rangeland Ecosystem Science Department; professor Earth Resources Department, Colorado State University, Fort Collins, Colo, 80523; professor, Civil Engineering Department, University of Wyoming, Laramie, Wyo, 82071 .

\begin{abstract}
A 2 year study was conducted to evaluate the effectiveness of riparian vegetation to filter sediment from overland water flow. Three vegetation height treatments: clipped to the soil surface, clipped to a $10 \mathrm{~cm}$ height, and undisturbed were evaluated in 2 montane riparian vegetation communities (grass and sedge) in northern Colorado. Water was sprayed on 2 macro-plots $(3 \mathrm{~m} \times$ $10 \mathrm{~m})$ and 2 micro-plots $(0.6 \mathrm{~m} \times 2 \mathrm{~m})$ simultaneously at a rate of $60 \mathrm{~mm} \mathrm{hr}^{-1}$ with a rotating boom rainfall simulator. Overland flow containing sediment was introduced at the upper end of the plots at a rate of $25 \mathrm{~mm} \mathrm{hr}^{-1}$ to simulate runoff and sediment transport from an upland area. Two sediment sources were used, a sandy loam soil and a ground silica sediment (loam). Thirty kg of sediment were added to each macro-plot and $1.2 \mathrm{~kg}$ of sediment were introduced to each micro-plot $\left(10 \mathrm{Mg} \mathrm{ha}^{-1}\right)$. Sediment yields, at the downslope end of the plot, were greater when the finer silica sediment was introduced into overland flow as compared with sediment derived from the sandy loam soil. As expected, the small micro-plots yielded more sediment and were often more sensitive to community and treatment differences than larger plots. We believe this resulted from the shorter travel distance. However, sediment filtration treatment effects were usually similar for both plot sizes. Sediment yields, measured at the outlet of the plots, did not decrease, or increase, as vegetation heights increased. Accurate prediction of sediment filtration from shallow flow in riparian zones required consideration of a combination of vegetation and soil surface characteristics.
\end{abstract}

Key Words: stubble height, erosion, vegetation filter strip, runoff, nonpoint source pollution

Livestock grazing in riparian zones concerns various resource users (Armour et al. 1994). Heavy livestock grazing in and adjacent to riparian zones may add sediment to streams during upland runoff events (Kauffman and Krueger 1984). High stream sedi-

Research was funded by USDA Competitive Grant - Water Quality Program, the Colorado State University Agricultural Experiment Station, and the Agricultura Research Service: At the time of the research the first author was a graduate research assistant, Rangeland Ecosystem Science Department Colorado State University.

Manuscript accepted 3 Jan. 1998. ment loads adversely impacts fish habitat and water quality (Rinne 1990, Platts 1991). The U.S. Forest Service developed vegetation standards that include minimum stubble heights to reduce problems related to runoff volume and water quality. These stubble height guidelines (i.e., $10-15 \mathrm{~cm}$ height) are intended to assure that sediment will be filtered from runoff, and therefore, reduce sediment delivery to streams (Clary and Webster 1989, 1990). However, these standards have not been tested under field conditions.

Research on stubble height as it might affect sediment filtration and stream water quality is minimal. Stubble heights have not been incorporated into the final analysis of other studies or were not intended by other studies authors' to represent effective methods to reduce sediment movement. Stubble height information often was used to represent changes in canopy cover, or as a management tool to determine when livestock were likely to graze less palatable vegetation (Hofmann et al. 1983, Simanton et al. 1991).

Most research on runoff and sediment filtration associated with vegetation cover has focused on distribution of vegetation, litter, and other variables (but not stubble height) that reduce scdiment loss from uplands (Kauffman et al. 1983a, 1983b; McCalla et al. 1984; Warren et al. 1986; Thurow et al. 1988; Rogers and Schumm 1991). Research in riparian zones on vegetation cover and other factors that might influence stream sediment load could not be found. Measurement of soil surface and vegetation characteristics, as they influence sediment deposition, should improve our understanding of sediment filtration in riparian ecosystems.

This study was conducted to evaluate the effect of vegetation stubble height, rainfall simulator plot size, plant communities, and soil surface characteristics on sediment filtration. We hypothesized that increased stubble height alone would not increase sediment filtration from shallow flows in a riparian zone, and that enhanced sediment filtration would require a combination of several vegetation and soil surface characteristics.

\section{Methods}

\section{Study Site}

We conducted the study during the summers of 1993 and 1994 in the riparian zone along Sheep Creek in the Roosevelt National 
Forest about $80 \mathrm{~km}$ northwest of Fort Collins, Colo. at 2,500 m elevation.

The Naz soil series dominates the Sheep Creek riparian zone. These are deep, well drained soils formed from granitic parent material. The sandy to clay loam soils are classified as coarse loamy pachic cryoborols. The surface layer is an A horizon, with high organic matter $(>7 \%)$ that ranges from 20 to $80 \mathrm{~cm}$ thick (USDA 1980). Slopes for the riparian zone study area ranged from 3 to $5 \%$.

\section{Plot Installation}

A 'Swanson type' large rotating boom rainfall simulator was located over paired $3 \mathrm{~m} \times 10 \mathrm{~m}$ plots (macro-plots) as outlined by Laflen et al. (1991). In addition to the paired $3 \mathrm{~m} \times 10 \mathrm{~m}$ plots, 2 additional plots, $0.6 \mathrm{~m} \times 2 \mathrm{~m}$ (micro-plots), were established on the outside and upper end of each of the macro-plots (Fig. 1). The 4 plots made up a test area (site) for each simulated rainfall event ( 12 sites were evaluated each year, 6 sites in a grass dominated community and 6 sites in a Carex dominated community). Metal sheets ( $15 \mathrm{~cm}$ wide) were driven $6 \mathrm{~cm}$ into the ground on 3 sides of each plot to contain and direct the runoff toward the downslope end of each plot (Simanton et al. 1991). The 2 plot sizes (macro and micro) at each simulation site allowed for comparisons of sediment yield and runoff under similar conditions for 2 different plot sizes.

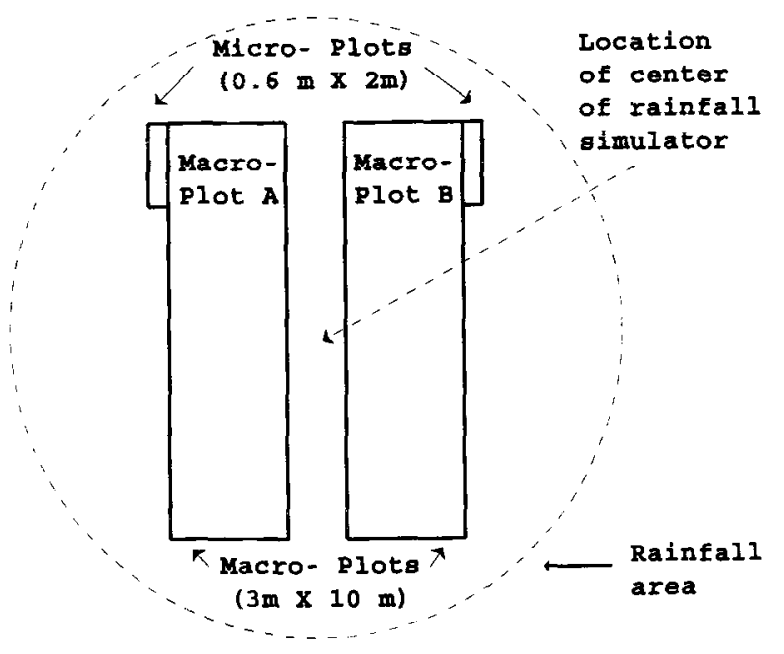

Fig. 1. Layout of plots for Sheep Creek rainfall simulations. The diagram shows location of micro- and macro-plots in relation to the rainfall simulator.

\section{Sampling}

Runoff and sediment at the downslope end of a macro-plot flowed into a collection trough and were directed into a critical depth flume. A bubble flow meter was used to record water depths through the flume at $1 \mathrm{~min}$ intervals. Flow data were converted to runoff rates. Runoff water samples were collected at the outlet of the flume at 5 designated times during the $30 \mathrm{~min}$ simulation period (Fig. 2). A $30-\mathrm{cm}$ recording rain gauge was used to measure the rate of water application. Six small plastic rain gauges located within each plot were used to measure total water and its distribution to each plot.

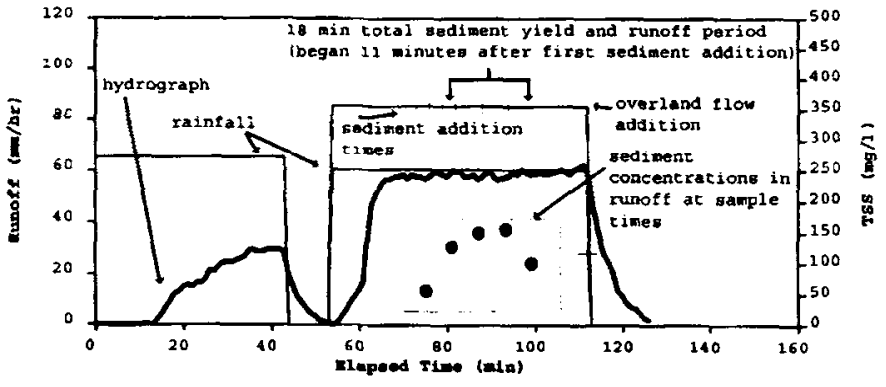

Fig. 2. Representative hydrograph and sedigraph for simulated rainfall and overland flow. The figure shows a preconditioning part of rainfall simulation with no overland flow addition, followed by a rest period, and then rainfall and overland flow simulation. Sediment additions are indicated on the overland flow line. Data indicate sediment concentrations at sample times.

Runoff and transported sediment from micro-plots were directed into $0.6 \mathrm{~m}$ wide $\times 5 \mathrm{~cm}$ high collection pans at the downslope end of the plots and were funneled to a $3 \mathrm{~cm}$ outlet where runoff samples were collected (Linse 1992). Runoff was calculated from the quantity of water collected in each bottle for a $15 \mathrm{sec}$ collection period. As with the macro-plots, runoff samples were collected from each micro-plot $5 \mathrm{~min}$ after runoff equilibrium had been reached and every $6 \mathrm{~min}$ thereafter.

\section{Simulation Run}

Rainfall was applied with the simulator at about $60 \mathrm{~mm} \mathrm{hr}^{-1}$ (no introduced overland flow) until equilibrium runoff was achieved, or up to a maximum time of $60 \mathrm{~min}$ if runoff equilibrium could not be attained (Frasier et al. 1998). The purpose of the initial simulation was to wet the soil so that all plots would have equal soil moisture. The preconditioning wetting was followed by a 30 min rest to allow infiltrated water to partially equilibrate in the upper layers of the soil profile.

Water was sprayed again on these plots after the rest period to simulate rainfall at a nominal rate of $60 \mathrm{~mm} \mathrm{hr}^{-1}$. Concurrent with the second rainfall application, a uniform overland flow was applied at the equivalent rate of $25 \mathrm{~mm} \mathrm{hr}^{-1}$. to the upper end of each plot (Fig. 2). This simulated runoff and scdiment transport from an upland area to the riparian zone. Slightly different amounts of water were recorded on some plots as a result of water supply fluctuations and wind interference (Frasier et al. 1998). A sloping $(6 \%)$ sheet metal platform $3.7 \mathrm{~m} \times 0.60 \mathrm{~m}$ at the upslope end of each pair of plots was used to introduce overland flow to the plots. Water from a spray bar with 6 nozzles was sprayed down onto the platform. One nozzle sprayed water on the part of the platform above the micro-plot, while 5 nozzles sprayed water on the platform leading to the macro-plot.

\section{Sediment Introduction}

Sediment of known particle size distribution and quantity was introduced into the overland flow for each plot. The introduced sediment for the first year (1993) of simulations was derived from an upland site in the Sheep Creek region. The soil was sieved through a $3 \mathrm{~mm}$ screen and mixed to achieve a consistant particle size distribution. Particle size distribution for the sandy loam introduced sediment was: $52.6 \%$ sand $(50-2000 \mu \mathrm{m})$, $31.2 \%$ silt $(2-50 \mu \mathrm{m})$, and $16.2 \%$ clay (less than $2 \mu \mathrm{m}$ ). 
The introduced sediment for the second year was a combination of 2 ground silica products. The first product was SIL-CO-SIL 250 , the second was MIN-U-SIL 5. These 2 products were mixed by weight as $60 \%$ SIL-CO-SIL 250 and $40 \%$ MIN-U-SIL 5. The resultant particle size distribution was: $31.6 \%$ very fine sand (greater than $50 \mu \mathrm{m}), 41.8 \%$ silt $(2-50 \mu \mathrm{m}$ ), and $26.6 \%$ clay (less than $2 \mu \mathrm{m})$. We used the silica in 1994 to test the effect of soil texture on sediment filtration.

Thirty kg of sediment was introduced to each macro-plot and 1.2 $\mathrm{kg}$ (equivalent to $10,000 \mathrm{~kg} \mathrm{ha}^{-1}$ ) was added to each micro-plot during each simulation run. The $30 \mathrm{~kg}$ and $1.2 \mathrm{~kg}$ levels were selected following pilot studies with $15 \mathrm{~kg}\left(5,000 \mathrm{~kg} \mathrm{ha}^{-1}\right)$ for each macroplot and $0.6 \mathrm{~kg}\left(5,000 \mathrm{~kg} \mathrm{ha}^{-1}\right)$ for each micro-plot. The $5,000 \mathrm{~kg}$ $\mathrm{ha}^{-1}$ represented actual levels of sediment that might reach riparian areas in overland flow (Buckhouse and Mattison 1980; Buckhouse and Gaither 1982). However, little or no sediment was measured in runoff from these pilot studies; therefore, the introduced sediment levels were doubled. Total sediment for each plot was bagged in 10 equal quantities and spread uniformly across the platform at $3 \mathrm{~min}$ intervals during the simulation run (Fig. 2).

\section{Community Treatments and Measurements}

Studies were conducted each year in 2 riparian vegetation communities: 1) a grass community of tufted hairgrass (Deschampsia caespitosa (L.) Beauv.), cinquefoil (Potentilla gracilis Dougl. ex Hook), Kentucky bluegrass (Poa pratensis L.), and sedges (Carex spp.), and 2) a sedge community of beaked sedge (Carex rostrata Stokes.) and water sedge ( $C$. aquatilis Wahl.). The 2 communities were located directly across Sheep Creek from one another. Thirty-three total species (both communities combined) were recorded within the plots. Three vegetation height treatments (i.e., stubble heights) were evaluated within each community [clipped to soil surface, $10 \mathrm{~cm}$, and unclipped $(27 \mathrm{~cm}$ mean for grasses and $45 \mathrm{~cm}$ mean for sedges)]. In the $10 \mathrm{~cm}$ clipping treatment, vegetation was harvested with a mower and the clipped material and surface litter was removed from the plots. Plots clipped to the soil surface were vacuumed with a commercial shop vacuum to remove all surface litter cover. Paired macro- and micro-plots for each simulation run had the same clipping treatment, i.e., all 4 plots (paired macro- and micro-plots) under the simulator during each simulation run had the same clipping treatment (Fig. 1). Two randomly assigned replications of paired vegetation height treatment plots (both macro- and micro-plots) occurred in each community during each year.

Soil surface, vegetation surface and canopy cover, and species composition, in each plot were determined with a point frame with 100 points per plot (Platts et al. 1987, Bonham 1989). We measured vegetation density using three $1 / 8 \mathrm{~m}^{2}$ circle frames per plot. We used a Zeiss Elta3 Total Station ${ }^{1}$ to measure plot slope and area (Zeiss 1986).

Vegetation biomass remaining after each stubble height treatment was sampled for each plot by clipping to ground level three $1 / 8 \mathrm{~m}^{2}$ circular plots in each macro-plot and one $1 / 8 \mathrm{~m}^{2}$ circular plot in each micro-plot after the rainfall simulation.

We estimated soil surface roughness (Hairsine et al. 1991) as the standard deviation of the height of 100 pins using an elevation table described by Linse (1992). The elevation table with 100 pins fit inside each micro-plot $(0.6 \times 2 \mathrm{~m})$ and measurements were taken for each micro-plot. Additionally, the table was placed lengthwise in the center of the upslope portion of each macro-plot and 100 points were measured.
Soil samples taken from the top $6 \mathrm{~cm}$ were dried at $109^{\circ} \mathrm{C}$ for 40 hours and ashed at $550^{\circ} \mathrm{C}$ for 5 hours (Storer 1984, Klute 1986) before hydrometer analysis (Allen 1990) was used to determined soil texture.

\section{Water Analysis}

Vacuum filtration through pre-weighed glass microfibre filters with Büchner funnels provided sediment yield from runoff samples. The filter papers plus sediment were oven-dried at $90^{\circ} \mathrm{C}$ and weighed. Sediment concentration for each sample time was multiplied by runoff rate to yield sediment output.

\section{Experimental Design and Data Analysis}

For consistency, data were analyzed for an $18 \mathrm{~min}$ runoff and sediment yield period starting $11 \mathrm{~min}$ after adding the first sediment (Fig. 2). Total nunoff was divided by the sum of applied rainfall and applied overland flow to calculate the fraction of applied water lost as runoff during the $18 \mathrm{~min}$ period. This normalized differences in rainfall and overland flow application rates among plots.

The experimental design was a repeated measures split-split plot with factorial arrangement of treatments (Steel and Torrie 1980).The study treatments were: 3 vegetation heights $(0,10 \mathrm{~cm}$, and natural vegetation height), 2 vegetation communities (sedgc and a grass-sedge complex), 2 plot sizes (micro- and macroplots), and 2 types of introduced sediment (sandy loam soil in year 1 and silica material in year 2) with 4 replications. Stubble height at a simulation site was a controlled factor, with vegetation cover, vegetation density, litter cover, species composition, surface roughness, bare ground, slope, and rock cover as measured factors. The experimental designs for the vegetation communities and plot locations were identical both years. Therefore, 24 macroplots $(3 \mathrm{~m} \times 10 \mathrm{~m})$ and 24 micro-plots $(0.6 \mathrm{~m} \times 2 \mathrm{~m})$ were evaluated each year of the study. Thus, there were 8 macro-plots and 8 micro-plots for each of the 3 vegetation height treatments that were assessed each year.

Multiple linear regression, analysis of variance (ANOVA) (Steel and Torrie 1980), and analysis of covariance (ANCOV) (Wildt and Ahtola 1978) described significant ( $\mathrm{P} \leq 0.05$ relationships among the vegetation, soil, and surface characteristics as they influenced runoff and sediment yield. A t-test described the significance of differences for 18 min sediment yield and runoff between the 2 plot sizes, 2 sediment types, and 2 vegetation communities (Steel and Torrie 1980). Significant ( $\mathrm{P} \leq 0.05$ ) differences among means and interactions were tested using least significant difference (LSD) comparisons (Steel and Torrie 1980, Hoppe 1993).

\section{Results and Discussion}

\section{Runoff}

Measured 18 min runoff may have differed between vegetation communities (grass $=28 \pm 3$ (Standard Error $(\mathrm{SE})$ ) vs sedge $=$ $\mathrm{mm} \pm 3(\mathrm{SE}))(\mathrm{P}=0.07)$, but not among vegetation height treatments $(P=0.19)$ The normalized 18 min runoff had similar ANOVA results for treatments as did the measured $18 \mathrm{~min}$ runoff. However, while not statistically different (at $P \leq .05$ ), the grass community did have about $20 \%$ more runoff $(P \leq 0.10)$ than 
the sedge community. The difference in runoff between communities was related to higher soil moisture in the grass community. Greater water infiltration in the sedge community was also evident by a longer period to reach equilibrium runoff on several sedge plots (Pearce 1995).

A significant interaction ( $P=0.01$ ) occurred between plot size and year for the $18 \mathrm{~min}$ total runoff. Micro-plots had more runoff $(\mathrm{P} \leq 0.05)$ in 1993 versus 1994 . However, runoff from macroplots did not differ between years (Fig. 3). We believe that greater runoff for micro-plots in 1993 resulted from greater antecedent soil moisture (1993 62\% water; 1994 43\% water). Runoff differed by plot size in both years, with more runoff $(\mathrm{P} \leq$ 0.05 ) produced from micro-plots than macro-plots (1993 micro$49 \mathrm{~mm} \pm 4$ (SE), macro- $15 \mathrm{~mm} \pm 1$ (SE); 1994 micro- $28 \mathrm{~mm} \pm$ 3 (SE), macro- $9 \mathrm{~mm} \pm 1(\mathrm{SE})$ ). Equilibrium flow was not achieved in $60 \mathrm{~min}$ in several macro-plots, and as much as 120 min was required to achieve initial runoff. While not timed, ocular observation of micro-plots runoff showed that nunoff occurred much sooner in the smaller plots of each simulation site, the increased travel distance for introduced overland flow in macroplots might partially explain this difference.

\section{Sediment Yield}

Sediment yield for the $18 \mathrm{~min}$ period did not differ among vegetation heights $(P=0.52)$ or vegetation communities $(P=0.42)$. However, a significant interaction $(P<0.01)$ between plot size and sediment type existed for sediment yield. Least significant difference (LSD) comparisons for this interaction indicated that no difference $(P>0.05$ ) existed in sediment yield from macroplots between the 2 types of sediment. However, more sediment ( $P \leq 0.05$ ) came from micro-plots when silica sediment was added (Fig. 4). The micro-plot difference occurred because silica sediment particles were smaller than Sheep Creek sediment particles. Therefore, a greater proportion of the silica sediment was transported in runoff (Haan et al. 1994). Also, silica sediment yields were greater from micro-plots than from macro-plots $(\mathrm{P} \leq$ 0.05). Lal (1994) found that sediment delivery ratio was greatly influenced by length of slope (plot size in our study). Therefore, we expected that the micro-plots would yield more sediment than macro-plots.

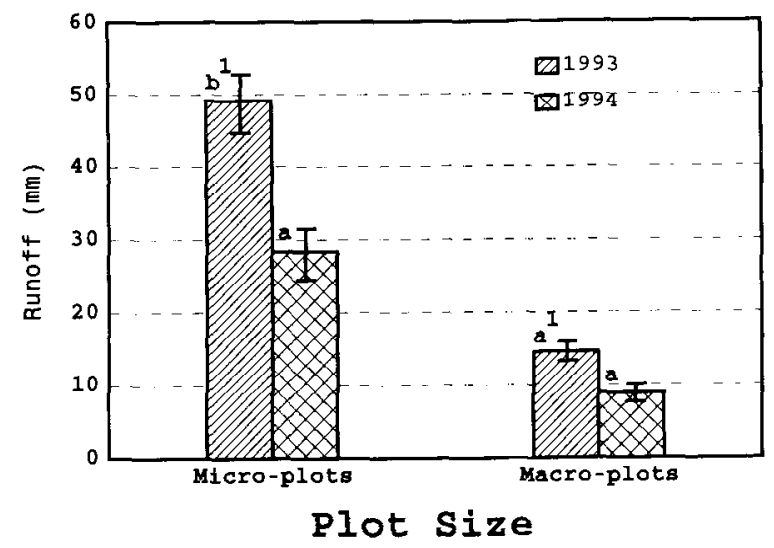

Fig. 3. Interaction between plot size and year for $\mathbf{1 8} \mathbf{~ m i n}$ runoff production. 'Means in a bar cluster with the same letter are not significnatly different $(P>0.05)$. Standard Error is shown as a vertical line within each bar.
Sediment filtration was efficient in both macro- and microplots $(98 \%$ of sediment remained in macro-plots and $94 \%$ remained in micro-plots). Each macro-plot received $30 \mathrm{~kg}$ of introduced sediment and only 0.07 and $0.66 \mathrm{~kg}$ per plot were collected in 1993 and 1994 respectively.

The 2 communities had significant differences in 18 min sediment yield when runoff was used as a covariate. Nearly $50 \%$ more sediment $(\mathrm{P} \leq 0.05)$ was transported through the sedge community ( $427 \mathrm{~kg} \mathrm{ha}^{-1} \pm 149$ (SE)) than through the grass community $\left(306 \mathrm{~kg} \mathrm{ha}^{-1} \pm 82(\mathrm{SE})\right)$. The higher density of vegetation and more uniform spacing of stems in the grass community may have created a more effective sediment filter than the sparsely spaced sedge tussocks (Table 1).

\section{Sediment Yield Over Time}

Sediment yield $\left(\mathrm{g} \mathrm{min}^{-1}\right)$ did not vary as a function of sample time ( $P=0.53$ ) (both micro- and macro plots). Apparently, similar amounts of suspended sediment were coming from the plot area throughout the sampled part of the rainfall simulation. Thus, use of an 18 min total sediment yield for rainfall simulation plots was a valid measure for comparisons among treatments.

\section{Prediction of Sediment Yield}

Multiple regression analyses did not yield a good model (the adjusted $r^{2}$ was 0.41 ) to predict sediment yield from vegetation characteristics (vegetation cover, vegetation density, litter cover, species composition) and soil surface variables (surface roughness, bare ground, slope, and rock cover). Too many variables such as slope (\%), density (stems $\mathrm{m}^{-2}$ ), forbs (\%), bare ground $(\%)$, silt content of soil (\%), clay content $(\%)$ of introduced sediment, and runoff ( $\mathrm{mm}$ ) were selected for the model (Table 1). Increasing the number of variables beyond 7 did not greatly increase the $r^{2}$ value and decreased the adjusted $r^{2}$ by 0.01 . A $\log (10)$ transformation of the dependent variable, sediment yield $\left(\mathrm{kg} \mathrm{ha}^{-1}\right)$, did improve the model (adjusted $\mathrm{r}^{2}=0.63, \mathrm{P}<0.01$ ). As with the non-transformed data, including more than 7 independent variables did not improve the model. Regression models with many variables do not have utility for land managers. Models with 3 or 4 variables, that could be used by land managers, could not be developed from our data.

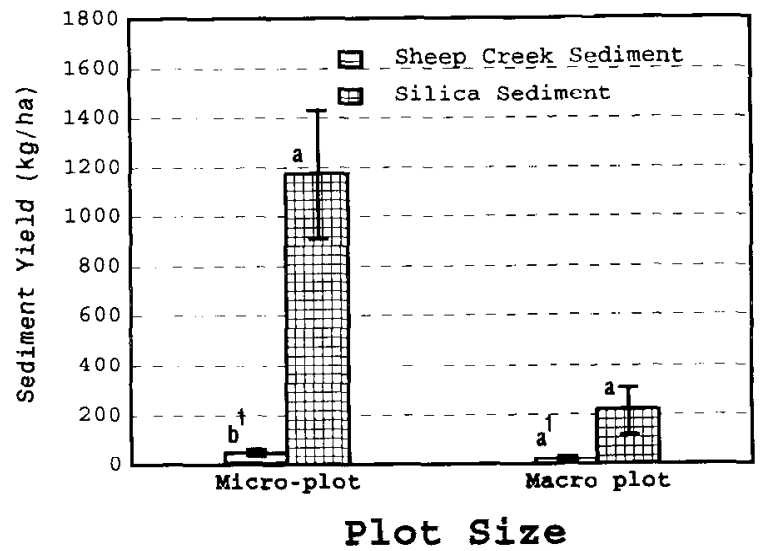

Fig. 4. Interaction between plot size and sediment type for $18 \mathrm{~min}$ sediment yield. ${ }^{1}$ Means in a bar cluster with the same letter are not significantly different $(P>0.05)$ Standard Error is shown as a vertical line within each bar. 
Table 1. Mean values and standard errors for variables selected in the sediment yield regression model when data were not transformed.

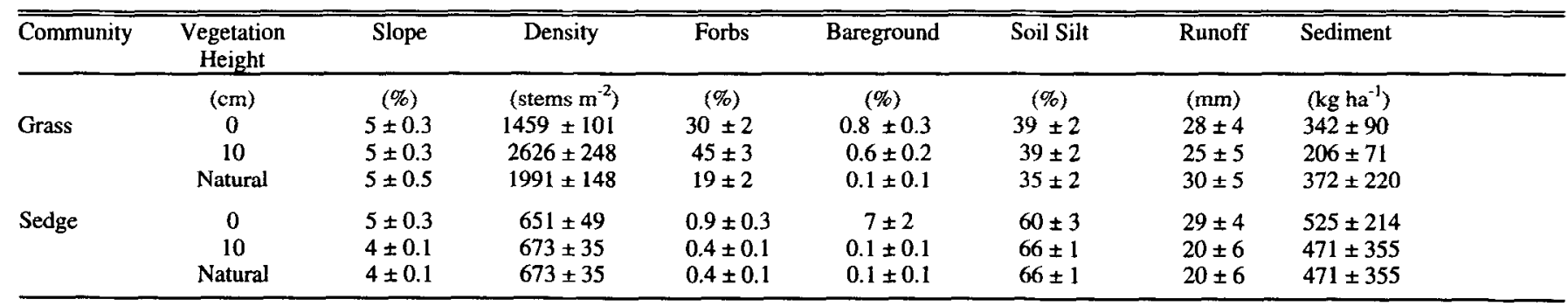

\section{Summary and Conclusions}

Small plot studies may exaggerate sediment transport as they had greater sediment output than larger plots under equal rainfall duration and intensity and equal runoff input per unit plot area. These results were similar to those of Mutchler et al. (1988). Sediment delivery ratios decrease as plot or watershed size increases (Lal 1994). In our study, increased sediment yield resulted from the shorter travel distance in the smaller plots. Therefore, larger simulation plots are recommended for predicting sediment yields for larger areas. However, smaller plots are easier to work with and are more sensitive to treatments than larger plots.

Particle size distribution of sediment in overland flow directly influences sediment yield. Finer particles move through riparian buffer zones better than larger particles. Therefore, assessment of the particle size distribution of upland sediment helps to determine appropriate vegetation filter width.

Vegetation height did not influence sediment yield from low flow rates simulated in this study. However, flow depths in this study were much shallower (less than $10 \mathrm{~cm}$ ) than the 2 taller vegetation heights sampled. Simanton et al. (1991) clipped rainfall simulation plots on 9 separate rangelands sites in Arizona and found no differences in sediment yield when vegetation was clipped to $2 \mathrm{~cm}$ as compared with unclipped vegetation. This study (Simanton et al. 1991) supports our findings that stubble height is not well correlated with sediment filtration. No other research results were found that related stubble height to sediment filtration in riparian zones.

It was apparent that riparian buffer strips were effective sediment filters, regardless of vegetation height or vegetation community. At least $98 \%$ of the introduced sediment remained within the rainfall simulation macro-plots (94\% remained within the microplots). These results are consistent with other studies on the effectiveness of vegetation filter strips as filters for nonpoint source pollution (Hayes et al. 1984, Guck et al. 1987, Dillaha et al. 1989, Muñoz-Carpena et al. 1992, Bretschko and Moser 1993, Osborne and Kovacic 1993, Daniels and Gilliam 1996, Pearce et al. 1997). These studies have shown that vegetation zones downslope from upland areas were effective filters for sediment and nutrients from overland flow as long as overland flow was shallow.

\section{Literature Cited}

Allen, T. 1990. Particle Size Measurement, 4th Ed. Chapman and Hall, New York, N.Y. 806 p.

Armour, C., D. Duff, and W. Elmore. 1994. The effects of livestock grazing on western riparian and stream ecosystem. Fisheries 19:9-12.
Bonham, C.D. 1989. Measurements for Terrestrial Vegetation. John Wiley and Sons, New York, N.Y. 338 p.

Bretschko, G. and H. Moser. 1993. Transport and retention of matter in riparian ecotones. Hydrobiologia 251:95-101.

Buckhouse, J.C. and R.E. Gaither. 1982. Potential sediment production within vegetative communities in Oregon's Blue Mountains. J. Soil Water Conserv. 37:120-122.

Buckhouse, J.C. and J.L. Mattison. 1980. Potential soil erosion of selected habitat types in the High Desert Region of central Oregon. J. Range Manage. 33:282-285.

Clary, W.P. and B.F. Webster. 1989. Managing grazing of riparian areas in the Intermountain Region. USDA-For. Serv. Gen. Tech. Rep. INT-263. 12 p.

Clary, W.P. and B.F. Webster. 1990. Riparian grazing guidelines for the Intermountain Region. Rangelands 4:209-212.

Daniels, R.B. and J.W. Gilliam. 1996. Sediment and chemical load reduction by grass and riparian filters. Soil Sci. Amer. J. 60:246-251.

Dillaha, T.A., R.B. Reneau, S. Mostaghimi, and D. Lee. 1989. Vegetative filter strips for agricultural nonpoint source pollution control. Trans. ASAE 32:513-519.

Frasier, G.W., M.J. Trlica, W.C. Leininger, R.A. Pearce, and A. Fernald. 1998. Runoff from simulated rainfall in 2 montane riparian communities. J. Range Manage. J. Range Manage. 51:315-322.

Guck, M.E., W.L. Magette, and P.W. McClellan. 1987. Evaluation of sediment deposition upslope from grass filters. Amer. Soc. Agr. Eng. Pap. No. 87-2088. 9 p.

Haan, C.T., B.J. Barfield, and J.C. Hayes. 1994. Design Hydrology and Sedimentology for Small Catchments. Academic Press, San Diego, Calif. 588 p.

Hairsine, P.B., C.J. Moran, and C.W. Rose. 1991. Recent developments regarding the influence of soil surface characteristics on overland flow erosion. Aust. J. Soil Res. 30:249-264.

Hayes, J.C., B.J. Barfield, and R.I. Barnhisel. 1984. Performance of grass filters under laboratory and field conditions. Trans. ASAE 27:1321-1329.

Hofmann, L., R.E. Ries, and J.E. Gilley. 1983 Relationship runoff and soil loss to ground cover of native and reclaimed grazing land. Agron. J. 75:599-602.

Hoppe, F.M. 1993. Multiple Comparisons, Selection, and Applications in Biometry. Marcel Dekker, Inc., New York, N.Y. 558 p.

Kauffman, J.B. and W.C. Krueger. 1984. Livestock impacts on riparian ecosystems and streamside management implications. a review. J. Range Manage. 37:430-437.

Kauffman, J.B., W.C. Krueger, and M. Vavra. 1983a. Effects of late season cattle grazing on riparian plant communities. J. Range Manage. 36:685-690.

Kauffman, J.B., W.C. Krueger, and M. Vavra. 1983b. Impacts of cattle on streambanks in northeastern Oregon. J. Range Manage. 36:683-685.

Klute, A. (Ed.) 1986. Methods of Soil Analysis. Part I. Physical and Mineralogical Methods. Amer. Soc. Agron. \& Soil Sci. Soc. Amer. Madison, Wisc. 1188 p.

Laflen, J.M., W.J. Elliot, J.R. Simanton, C.S. Holzhey, and K.D. Kohl. 1991. WEPP soil erodibility experiments for rangelands and cropland soil. J. Soil and Water Conserv. 46:39-44.

Lal, R. 1994. Soil Research Methods. St. Lucia Press Inc., Delray Beach, Fla. $340 \mathrm{p}$. 
Linse, S.J. 1992. The influence of ground cover on upland range erosion M.S. Thesis. Univ. Wyoming., Laramie, Wyo. 98 p.

McCalla II, G.R., W.H. Blackburn, and L.B. Merrill. 1984. Effects of livestock grazing on sediment production, Edwards Plateau of Texas. J. Range Manage. 37:291-294.

Mutchler, C.K., C.E. Murphree, and K.C. McGregor 1988.Laboratory and field plots for soil erosion studies. pp. 9-36. In R. Lal (ed.) Soil Erosion Methods. Soil and Water Conserv. Soc. Ankeny, Iowa.

Muñoz-Carpena, R., J.E. Parsons, and J.W. Gilliam. 1992. Vegetative filter strips: modelling hydrology and sediment movement. Amer. Soc. Agr. Eng. Pap. No. 92-2625. 19 p.

Osborne, L.L. and D.A. Kovacic. 1993. Riparian vegetated buffer, strips in water-quality restoration and stream management. Freshwater Biol. 29:242-258.

Pearce, Robert A., M.J. Trlica, Wayne C. Leininger, James L. Smith, and Gary W. Frasier. 1997. Efficiency of grass buffer strips length and vegetation height on sediment filtration in laboratory rainfall simulations. J. Environ. Qual. 26:139-144.

Pearce, Robert A. 1995. Sediment movement and filtration within laboratory and riparian vegetation buffer strips. Ph.D. Diss., Colorado State Univ., Fort Collins, Colo. 191 p.

Platts, W.S. 1991. Influences of forest and rangeland management on salmonid fishes and their habitats. Amer. Fish. Soc. Spec. Pub. 19:389-423.

Platts, W.S., C. Armour, G.D. Booth, M. Bryant, J.L. Bufford, P. Cuplin, S. Jensen, G.W. Lienkaemper, G.W. Minshall, S.B. Monsen, L. Nelson, J.R. Sedell, and J.S. Tuhy. 1987. Methods for evaluating riparian habitats with applications to management.USDAFor. Serv. Gen. Tech. Rep. INT-221. 177 p.
Rinne, J.N. 1990. The utility of stream habitat and biota for identifying potential conflicting forest land uses montane riparian areas. For. Ecol. Manage. 33/34:363-383.

Rogers, R.D. and S.A. Schumm. 1991. The effect of sparse vegetation cover on erosion and sediment yield. J.Hydrol. 123:19-24.

Simanton, J.R., M.A. Weltz, and H.D. Larsen. 1991. Rangeland experiments to parameterize the water erosion prediction project model: vegetation canopy effects. J. Range Manage. 44:276-282.

Stcel, R.G.D. and J.H. Torrie. 1980. Principles and Procedures of Statistics: A Biometrical Approach. McGraw-Hill, New York, N.Y. $633 \mathrm{p}$

Storer, D.A. 1984. A simple high volume ashing procedure for determining soil organic matter. Comm. Soil Sci. Plant Anal. 15:759-772.

Thurow, T.L., W.H. Blackburn, and C.A. Taylor, Jr. 1988. Infiltration and interrill erosion responses to selected livestock grazing strategies, Edwards Plateau, Texas. J. Range Manage. 41:296-302.

USDA Soil Conservation Service and Forest Service. 1980. Soil survey report. Larimer County area, Colorado. Naz 70 soil series. U.S. Govt. Print. Off.:239-812/48.Wash., D.C.

Warren, S.D., W.H. Blackburn, and C.A. Taylor. 1986. Soil hydrologic response to number of pastures and stocking density under intensive rotation grazing. J. Range Manage. 39:500-504.

Wildt, A.R and O. Ahtola. 1978. Analysis of covariance. Sage University paper series on quantitative applications in the social sciences, Series no. 07-012. Sage Publ., Beverly Hills, Calif. 93 p.

Zeiss, C. 1986. Operating Instructions Elta3 Total Work Station. Oberkocher, West Germany. 